\title{
Ventos de mudança: a ficção científica brasileira e a transição democrática
}

\section{Winds of change: the brazilian science fiction and the democratic transition}

\author{
Marcello Simão Branco ${ }^{1}$
}

\begin{abstract}
Resumo
Dos anos 1970 até o início dos 1980 a ficção científica brasileira quase cessou suas atividades, com uma queda profunda nas atividades dos fãs e na publicação de obras de autores nacionais. Este intervalo, contudo, é chamado de "Onda Utópica/Distópica", pois se publicou obras que criticava o regime militar, por autores vinculados ao mainstream literário. Este artigo argumenta que este período não é homogêneo em termos temáticos, pois é possível destrinchar as obras - por meio da análise comparativa de seus conteúdos políticos -, mostrando que a partir do início dos anos 1980, os temas da FC brasileira apresentavam especulações sobre as alternativas que se abriam ao país no contexto do processo de abertura política, que conduziria à redemocratização.
\end{abstract}

Palavras-chaves: Ficção científica brasileira. Regime militar. Redemocratização.

\section{Summary}

From 1970s until the early 1980s the Brazilian science fiction almost ceased its activities, with a sharp drop in the activities of the fans and the publication of works of national authors. This range, however, is called "Wave Utopian/dystopian", because it published articles critical of the military regime, by authors belonging to the literary mainstream. This article argues that this period is not homogeneous in thematic terms, it is possible to tease out the works-throught a comparative analysis of its political content-showing that from the early 1980s, the themes of Brazilian CF were speculatios abot the alternatives that were open to the country in the context of political liberalization process, wich would lead to democratization.

Keywords: Brazilian science fiction. The military regime. Democratization.

\footnotetext{
${ }^{1}$ Doutor em Ciência Política pela Universidade de São Paulo, professor Adjunto da Universidade Federal de São Paulo (UNIFESP). E-mail: marcellobranco@ig.com.br.
} 
Se a história política brasileira é marcada por instabilidade política crônica, com alternância de regimes democráticos e autoritários ao longo do século XX, os 21 anos de ditadura militar podem ser considerados os mais repressivos, especialmente nas relações entre o Estado e a sociedade, que sempre foi problemática no Brasil. Isso porque em nossa História primeiro construiu-se o Estado - de caráter essencialmente patrimonialista e autoritário - para depois se desenvolverem relações sociais mais autônomas, que demorou em forjar identidades e, ainda mais tarde, um sentimento comum de nacionalidade. (CARVALHO, 2011).

As duas décadas de autoritarismo militar (1964 a 1985) transformaram de várias maneiras esta relação entre o Estado e a sociedade, a começar pelo inédito grau de repressão social e violência cometida por agentes do Estado, e o caráter modernizante da economia, acentuando um profundo processo de industrialização do setor privado e burocratização do setor público.

Em termos artísticos a sociedade reagiu de formas diversas ao autoritarismo militar, primeiro no contexto libertário dos anos 1960 (cinema novo, tropicalismo), depois nos "anos de chumbo", mais propriamente situados entre dezembro 1968 e março de 1974, a partir da vigência do Ato Institucional no. 5 e o governo que o executou, do presidente Emílio Garrastazu Médici. Neste período as manifestações artísticas sofreram diversas formas de repressão e censura, incluindo a prisão e o exílio de artistas e intelectuais.

No contexto mais específico da literatura, e ainda mais particularmente, a do gênero ficção científica, uma geração de fãs e escritores que conviviam numa comunidade (fandom) foi interrompida, além do número de obras de autores vinculados ao gênero também decrescer dramaticamente. Por curioso que possa parecer, uma das respostas mais efetivas à repressão desenfreada veio de escritores vinculados ao mainstream literário, que publicaram obras de ficção científica de caráter crítico ao regime, mas por meio das distopias, com uso destacado de situações metafóricas. Conforme mostraram Causo (1998) e Ginway (2005), há mesmo um conjunto interessante de obras que dialogaram criticamente com o autoritarismo, com algumas características que ajudam a entender de maneira singular a política e a cultura do país naquela época.

Os anos posteriores aos "de chumbo" são nomeados, de forma também significativa, de "abertura", iniciada pelo general Ernesto Geisel, quando assume a presidência em 1974 até o fim da presença militar no poder, em março de 1985 , num processo final conhecido como a da transição democrática, que permitiu a troca de poder entre os militares e os civis.

Neste sentido, a premissa que justifica este artigo é de que se os anos 1970 foram caracterizados como os da ficção distópica, os anos 1980 poderiam ser considerados como os de uma ficção da abertura, ou ainda uma ficção da transição, como resultado do fim do período autoritário e a retomada do regime democrático no país?

O artigo pretende explorar esta premissa analisando algumas obras destes anos, principalmente Não Verás País Nenhum, de Ignácio de Loyola Brandão (1981), seguidas de $A$ Invasão, de José Antonio Severo (1979); A Ordem do Dia, de Márcio Souza (1983); Silicone XXI, de Alfredo Sirkis (1985); e Horizonte de Eventos, de Jorge Luiz Calife (1986).

É interessante observar que procuramos refletir um pouco mais sobre a periodização realizada por Ginway e Causo (2010), que situam a ficção distópica entre 1972 e 1985 . Acontece que segue as características dos períodos históricos da ficção científica brasileira, ${ }^{2}$ mas

\footnotetext{
${ }^{2}$ Como movimento literário organizado em termos de atividades de fãs e publicações de livros de autores nacionais, a ficção científica brasileira pode ser classificada numa Primeira Onda (1958-1972) e numa Segunda Onda (1982-2004). Mais recentemente, há características que identificam uma terceira. Ver Ginway e Causo (2010).
} 
leva pouco em conta aquilo que procuramos abordar neste trabalho, uma alteração nas características deste período, chamada de fiç̧ão de abertura, que teria abordado temas mais próximos deste período de transformação sociopolítica e endereçado o gênero para uma nova fase, a da Segunda Onda, no período da redemocratização.

O objetivo deste trabalho, portanto, tem caráter exploratório, no sentido de formular hipóteses sobre a eventual relevância crítica destas obras como intérpretes deste período da história brasileira, primeiro se no mesmo patamar de contribuição que as obras da ficção distópica; segundo nas possíveis contribuições que elas podem trazer para entendermos o processo de abertura-transição política e em terceiro, do que estas obras têm de importantes para o enriquecimento da própria ficção científica no país, e o diálogo que estabeleceriam com a nova geração de fãs e escritores que surgiu nos anos 1980.

Para contextualizarmos o período histórico, será visto a seguir uma recapitulação dos anos da abertura (1974-1985), acentuando as características dos atores políticos e sociais que permitiram a transição do autoritarismo para a redemocratização. Na sequência, será abordada a ficção científica produzida durante o regime autoritário, nomeada como ficção distópica, entre os anos 1970 até meados de 1980. Primeiro ilustraremos como as obras do período mais repressivo dialogaram com as características da política e da sociedade. Mas a intenção não é de caráter exaustivo - pois isso já foi feito por outros autores -, mas de compreender de se a análise destas obras nos ajuda a verificar se as obras posteriores, dos anos 1980, tiveram um grau de sensibilidade semelhante, tanto do ponto de vista crítico, como especulativo, isto é, de possíveis tendências vislumbradas para o futuro político mais democrático do país.

A assim chamada "ficção de abertura" será analisada na sequência, procurando identificar suas principais características, tanto com a ficção científica em geral, como com o contexto político da época. Neste sentido, o romance Não Verás País Nenhum
(1981), é identificado como de transição entre a ficção distópica e esta nova que se afigura, e ganha destaque especial nesta análise que procura enxergar pela ótica privilegiada da ficção científica, o momento histórico de mudança de regime político no país.

O texto será concluído com as principais hipóteses levantadas, bem como uma reflexão final sobre a eventual relevância (e permanência) destas obras - tanto para a análise da política nacional, como de contribuição para a ficção científica do país.

\section{O Contexto Político}

Em linhas gerais podemos situar a ditadura militar em três fases diferentes e complementares. A primeira a da instalação do regime, com uma repressão moderada e com direitos civis e políticos em crescente restrição. Esta instalação moldou as bases do regime, na medida em que alterou as regras eleitorais e partidárias, excluiu centenas de civis e militares da vida política e, principalmente, outorgou uma nova Constituição, em 1967 (com reforma em 1969) dando, digamos assim, uma moldura legal à nova situação política do país.

Vale destacar também que este novo período autoritário rompeu com a tradição política dos líderes populistas, agora com os militares assumindo diretamente o poder e, mais significativo, adotando uma perspectiva modernizante, pela aliança entre o Estado, o capital nacional e o aumento do capital internacional. Este novo tipo de autoritarismo - que também foi adotado na Argentina, Chile e Uruguai - foi conceituado como um regime burocráticoautoritário. (O’DONNELL, 1990).

Numa segunda etapa, entre 1968 e 1974, tivemos a consolidação do regime, a partir da decretação do Ato Institucional n. 5. Este período é marcado por uma alta repressão política, com fechamento do Congresso Nacional por um curto período, cassação de políticos, censura à imprensa e às artes em geral, aumento das prisões de militantes políticos. Sem espaços legais de atuação, grupos de 
esquerda partem para luta armada nas cidades e no campo (1969-1973). Ao mesmo tempo, o país vive um processo de vigoroso crescimento econômico, o chamado período do "milagre", com uma média de aumento do Produto Interno Bruto (PIB), de $10 \%$. Esta prosperidade beneficiou a classe média que, somado à censura generalizada e as ações de repressão do Estado, isolou ainda mais os militantes que aderiram às armas para combater o regime.

A terceira fase é justamente a da chamada abertura, iniciada em 1974 com a posse à presidência do general Ernesto Geisel. Tem início a liberalização do regime autoritário, nas palavras de Geisel em sua posse a intenção era distencionar o ambiente político, com uma "abertura lenta, gradual e segura.”. De fato, o processo de liberalização que conduziu à transição do autoritarismo para a democracia levou exatos 11 anos, o mais demorado entre todas as experiências autoritárias daquela época, tanto na América Latina, como no Sul da Europa.

Desde o golpe de 1964 os militares se dividiam em duas correntes políticas. A primeira era a dos moderados, o chamado grupo da Sorbonne, formada por militares de convicções mais liberais, embora com uma noção limitada da participação democrática. Pertenciam a este setor os generais Castelo Branco - o primeiro presidente -, Golbery do Couto e Silva e Ernesto Geisel, entre outros. A segunda corrente era formada pelos radicais, os chamados "linhas-duras", com grande aversão ao comunismo e formas mais participativas de ação política, numa visão de mundo mais conservadora. Para eles, de maneira geral, os civis eram corruptos e incompetentes e cabia a eles, militares, a liderança do processo de transformação do Brasil numa potência econômica e militar. Seguiam mais fielmente a cartilha da Doutrina de Segurança
Nacional e Desenvolvimento, formulada pelos quadros da Escola Superior de Guerra, desde fins dos anos $1940 .^{3}$

Para Geisel e Golbery este setor, que teve a presidência por dois mandatos, de Costa e Silva (1967-1969) e Médici (1969-1974), os linhasduras foram longe demais no grau de repressão à sociedade. A situação econômica também não era mais tão favorável, depois do primeiro choque do Petróleo, em 1973, que provocou uma alta generalizada dos preços, num processo inflacionário que só iria crescer pelos anos seguintes. Antes que a legitimidade alcançada com o êxito econômico ficasse mais abalada era preciso tornar o regime menos repressivo.

Outra preocupação do grupo dos militares moderados era com relação à própria unidade corporativa das Forças Armadas. Principalmente a partir do AI-5, houve uma divisão de comandos e atribuições em três segmentos: as Forças Armadas enquanto governo (responsável pela administração do país); instituição (atividades militares tradicionais) e segurança (responsável pela repressão aos opositores). Este último segmento cresceu demais em importância e poder entre 1968 e 1974, com o aumento das prisões, torturas, desaparecimentos, exílios e censuras de toda ordem. Forjou também a criação de sombrios grupos paramilitares de apoio, como o Comando de Caça aos Comunistas (CCC) e a Operação Bandeirante, financiadas em parte por grupos privados. Para Geisel e Golbery era preciso reduzir esta repressão, porque o crescimento desta comunidade de segurança - formada por oficiais de baixa e média patente - crescera demais e ameaçava a própria hierarquia das Forças. (STEPAN, 1986). Além disso, não cabia bem para a imagem profissional de uma corporação o estigma de torturadores.

${ }^{3}$ Estas duas correntes não eram homogêneas, com alguns militares assumindo posições entre uma e outra, de acordo com eventos de conjuntura. O que podemos dizer é que se consolidaram, ao longo do autoritarismo, como correntes predominantes. 
Como já assinalado, o segmento moderado cultivava uma visão mais liberal da sociedade, entendendo que não cabia, no longo prazo, aos militares se envolverem com assuntos políticos, e que o Brasil não deveria conviver indefinidamente com um regime autoritário. Em suma, o objetivo final era restaurar a democracia.

Este movimento não era unívoco, pois o governo recebeu uma indicação clara da sociedade. Nas eleições legislativas federais de 1974, poucos meses depois de Geisel assumir a presidência, o partido da oposição (MDB) surpreendeu derrotando pela primeira vez o partido do governo (Arena). Na eleição do Senado Federal, o MDB elegeu 16 senadores de um total de 22 em disputa $(72,7 \%)$, e na eleição para a Câmara dos Deputados elegeu 161 de um total de 364 cadeiras (44,2\%) (LAMOUNIER, 1990). Embora descontente com o resultado eleitoral, o governo percebeu que poderia (e deveria) incorporar no projeto de liberalização os setores moderados da oposição, isolando, desta forma, os setores militares e civis mais radicais.

Desta forma, o processo de abertura política ganhou gradativamente a adesão do MDB e de diversos setores da sociedade civil, como os profissionais liberais (imprensa e advogados, à frente), os sindicatos, empresários e a igreja católica. Setores que em sua maioria, com exceção do movimento sindical, apoiaram o golpe em 1964, mas viram-se vítimas do alto grau de repressão no período de 1968 a 1974.

O processo não foi, contudo, linear. Em certos momentos o governo adotou comportamentos dúbios, provocando dúvidas na oposição política e na sociedade. Um exemplo foi no "Pacote de Abril", de 1977, quando baixou uma série de medidas para restringir a competição eleitoral do ano seguinte por receio de perder a maioria nas casas do Congresso Nacional. Censura ao horário eleitoral na TV, aumento das vagas para deputados federais para os estados menos populosos do Norte e do Nordeste, criação de um cargo de senador indicado pelo governo estadual, ${ }^{4}$ foram algumas das principais medidas. (SKIDMORE, 1988).

Outro exemplo é que as forças militares mais radicais tentaram resistir ao processo de abertura. Primeiro com assassinatos de militantes do PCB em 1974 e 1975, e depois de ativistas sociais, como o jornalista Vladimir Herzog, em 1975, e o operário Manuel Fiel Filho, em 1976, além do atentado ao Rio Centro em 1981. Tentativas frustradas de enfraquecer o governo e que permitiram o aumento da pressão de setores da sociedade em direção à democratização. ${ }^{5}$

$\mathrm{Na}$ verdade o governo não dava sinais contraditórios - como se pensou à época no calor dos acontecimentos -, mas queria comandar o processo ao seu modo, com receio de perder o controle sobre o avanço da oposição e de sofrer reações dos setores radicais das Forças Armadas. Do ponto de vista partidário-eleitoral outra medida de controle do processo foi o fim do bipartidarismo, em 1979. Aos partidos existentes somaram-se outros. Ao invés de significar uma abertura por mais liberdade de organização política - em todo caso, não deixou de ser - o objetivo de Golbery era dividir a oposição para que o governo pudesse manter a maioria na Câmara, no Senado e no Colégio Eleitoral que

\footnotetext{
${ }^{4}$ Foi o chamado "senador biônico", uma referência bem-humorada à série de TV que fazia sucesso na época, O Homem de Seis Milhões de Dólares, que tinha como personagem principal um homem biônico.

${ }^{5}$ Nestes mesmos anos houve mudanças no contexto internacional com relação aos regimes autoritários. Grécia e Portugal viveram processos de redemocratização em 1974, e a Espanha em 1975, o que, por si só, desgastou a imagem das ditaduras em outras regiões do mundo. Além disso, o governo norte-americano de Jimmy Carter não apoiava em caráter unilateral as ações dos regimes autoritários na América Latina, como as torturas e perseguições políticas. A pressão de Washington neste momento foi bem aproveitada por setores da oposição no Brasil para descontentamento de Geisel e seus aliados, que não queriam ingerência externa na política que eles comandavam.
} 
escolheria o general João Figueiredo à presidência em 1979.

Outras medidas liberalizantes foram sendo tomadas, negociadas com os partidos de oposição, mas controlados pelo governo. Assim foi a revogação do AI-5 e da censura-prévia, em 1978, e a aprovação da lei de Anistia, em 1979 (que permitiu o retorno ao país de vários exilados políticos $)^{6} \mathrm{e}$, finalmente, a volta da eleição direta para os governos estaduais, em 1982.

Neste processo de abertura política tivemos a emergência de uma maior organização da sociedade civile de movimentos sociais, que também contribuiu para o contexto em que, aos poucos, o processo se acelerou em direção à transição democrática. Especialmente importantes foram o chamado novo sindicalismo, o papel mais progressista da Igreja Católica e associações vinculadas à classe média, como a Ordem dos Advogados do Brasil $(\mathrm{OAB})$ e a Associação Brasileira de Imprensa (ABI), em consonância com boa parte dos grandes órgãos de comunicação do país. O sindicalismo foi renovado, depois de uma década de ocaso desde as repressões às greves de Osasco (SP) e Contagem (MG), em 1968. Uma atividade sindical menos politizada e mais pragmática surgiu na principal região industrial do país, o $\mathrm{ABC}$ paulista que, em meio às demandas gerais da sociedade por mais democratização, transformou-se num movimento político importante, entre o final dos anos 1970 e início dos 1980.

Embora a Igreja Católica em sua maioria tenha apoiado o golpe em 1964, condenou as torturas e os assassinatos cometidos pelos grupos guerrilheiros e principalmente pelo Estado. Exerceu um papel de relevo nas negociações por maiores aberturas políticas dentro do regime e organizou associações populares, baseadas menos na ação política em si, e mais em reivindicações por melhores condições sociais às camadas mais pobres da população. Foram criadas assim, as Comunidades Eclesiais de Base (CEBs), pólos de apoio para um vínculo mais popular do catolicismo, desvinculando, em parte, sua imagem com o poder constituído.

Numa decorrência dos dois processos anteriores, várias associações de bairros foram criadas, num movimento associativista que procurava reivindicar, num primeiro momento, a melhoria de condições de vida no entorno, mas que foi capitalizada politicamente na formação de lideranças que posteriormente entraram para a atividade partidária, sobretudo nos partidos opositores, como o PT e o PMDB. Mesmo no interior de um regime autoritário militar percebe-se que o processo de industrialização e urbanização da sociedade brasileira permitiu o surgimento de incipientes atividades por mais cidadania. (AVRITZER, 2000).

Dentro do contexto da liberalização dois fatores demarcam mais claramente como se passou $d o$ processo de abertura para o processo de transição, que conduziu à saída dos militares, em março de 1985.

O primeiro deles relaciona-se com a crise econômica grave que o país viveu a partir do início dos anos 1980. Um conjunto de fatores relacionados aprofundou um cenário que já estava em deterioração desde meados dos anos 1970. A inflação saiu de controle, atingindo dois dígitos mensais, a dívida externa subiu bruscamente com uma taxa de juros elevada em $12 \%$, tornando-se a maior do mundo. Em 1982 o governo se declara sem condições de pagar a dívida e recorre ao Fundo Monetário Internacional (FMI), para negociá-la. Com isso soma ao desprestígio político o descrédito

\footnotetext{
${ }^{6}$ Tanto o processo foi controlado pelo governo que a anistia "geral e irrestrita" valeu tanto para os opositores como para os acusados pertencentes ao governo de graves abusos dos direitos humanos. Os termos desta lei continuam controversas mesmo depois de mais de 30 anos de sua vigência, e a instauração em 2012 da Comissão da Verdade não deve alterar a sua condição.
} 
econômico. Aumentou o desemprego e o ritmo de produção da indústria diminuiu.

Contribuiu para a crise também o fato do Estado brasileiro ter aumentado em demasia sua participação na economia, com projetos enormes de infra-estrutura, protecionismo em vários setores, e criação de barreiras para importação de vários produtos. Com um Estado intervencionista e uma economia desestimulante para o investimento estrangeiro, não houve como enfrentar o súbito agravamento do cenário. A crise desgastou o governo junto à opinião pública, pois por ser um regime autoritário não tinha legitimidade política para se manter sob uma crise destas proporções.

Em paralelo, governo e sociedade civil estavam em pleno processo de negociação dentro do contexto de abertura política. A crise econômica deu mais motivos para que a oposição organizada questionasse não só a legitimidade, mas a capacidade do governo em enfrentar o cenário econômico desfavorável.

A volta das eleições diretas para os governos estaduais significou uma espécie de plebiscito sobre o desempenho do governo federal. Suspensas desde 1965 foi a mais importante eleição realizada sob o domínio dos militares. Os partidos de oposição elegeram 10 governadores, dos 22 em disputa e tiveram como eleitos os governos de três dos mais importantes estados do país, São Paulo, Rio de Janeiro e Minas Gerais.

A partir da posse dos governadores, em março de 1983, o Brasil viveu a curiosa situação de estar sob escolha democrática em nível subnacional e autoritária em nível nacional. ${ }^{7}$ Desta forma, a pressão pela redemocratização ganhou impulso com a liderança dos governadores destes três estados e, um deles, acabou escolhido para concorrer à sucessão de Figueiredo, o governador de Minas Gerais Tancredo Neves.

A negociação em torno da sucessão, primeiro ganhou as ruas, com o movimento Diretas-Já no primeiro semestre de 1984. Comícios com a presença de centenas de milhares de pessoas por todo o país mostraram aos militares que era tempo de se retirarem depois de duas décadas. Contudo, o governo federal mostrou força e impediu a aprovação da emenda constitucional que reestabeleceria as eleições diretas para presidente. Os militares aceitavam deixar o poder, mas teria de ser realizado nos termos deles - como, aliás, estava claro no plano de Geisel e Golbery desde 1974.

O que chama a atenção no caso brasileiro também é que a oposição aceitou os termos do governo federal, pois indicou um candidato mais conservador como seu representante ao invés de, por exemplo, nomes como Ulysses Guimarães ou Leonel Brizola. De fato houve um intenso e complexo campo de negociações - também para definir o candidato do governo -, em que o tom adotado foi o da moderação. Os militares aceitavam deixar o poder, sem nem mesmo definir com clareza que candidato apoiaria, ${ }^{8}$ e a oposição se comprometeria a adotar um comportamento moderado ao assumir o poder. Ou seja: os radicais linhas-duras das Forças Armadas e a oposição mais ideológica - como a do PT - estiveram fora do processo de negociação da transição, na chamada transição pactuada. (BRANCO, 2007a). ${ }^{9}$

7 Os outros países sul-americanos com regimes autoritários neste período passaram pelo caminho mais tradicional. Foram encerrados com uma eleição direta em nível nacional.

80 presidente João Figueiredo não tinha entusiasmo por nenhum dos nomes à disposição, como o ministro da Agricultura, o coronel Mário Andreazza, e os civis Aureliano Chaves (vice-presidente, que tinha a simpatia de Geisel) e o ex-governador de São Paulo, Paulo Maluf, que acabou sendo o candidato, mas sem apoio do governo e de parte do PDS (ex-Arena) - partido da situação. (Revista Veja, n. 854, 1985).

9 Os radicais militares além de não quererem o fim da ditadura, desejavam retornar a um governo mais repressivo, como entre 1968-1974. Já os civis radicais - compostos por setores mais à esquerda e presentes na luta armada - queriam adotar um tipo de 
Neste processo percebe-se que os diversos setores da sociedade civil que se engajaram no apoio político às lideranças oposicionistas e, mais que isso, mobilizaram a população no movimento das Diretas-Já, viram-se à margem do processo de negociação entre o setor da elite militar e da elite oposicionista que negociaram os termos da transição. Certamente isto frustrou em parte o apoio ao novo governo civil que assumiu em março de 1985, pondo fim há 20 anos, 11 meses e 16 dias de presença autoritária dos militares no poder. Ademais, contribuiu para isso também a morte surpreendente de Tancredo Neves, vindo a assumir de fato a Presidência o vice-presidente José Sarney, uma liderança egressa do partido que apoiou o regime militar.

Devido a estas particularidades, os primeiros anos da transição foram difíceis para institucionalizar o novo regime democrático. Sarney herdou uma coalizão de apoio que ele não formou, e teve de fazer muitas concessões ao PMDB para poder governar num cenário de crise econômica cada vez mais grave, a memória recente dos militares e uma sociedade ávida por recuperar seus direitos políticos e uma melhor condição de vida.

A transição democrática completa o seu ciclo em duas etapas subsequentes e fundamentais: 1) a promulgação da nova Constituição, em 1988 e 2) a eleição direta para presidente em 1989. A partir daí, mesmo com a crise política que afastou Fernando Collor do Executivo em 1992, o país já estava vivendo de maneira normal em um novo regime político, o democrático.

\section{Das Distopias para a Abertura}

A literatura brasileira abordou de diferentes maneiras as duas décadas de presença militar no poder, com especial intensidade crítica nos chamados "anos de chumbo", o momento de maior violência política, entre 1968 e 1974. Este período, em especial, "serviu para aumentar a virtuosidade e a sofisticação dos escritores que, ao se posicionarem de forma satírica e agressiva contra a repressão política, criticavam os supostos benefícios da tecnologia e do desenvolvimento" (GINWAY, 2010, p. 183-184). Ainda de acordo com a pesquisadora norte-americana predominaram três correntes principais na ficção da época: romancesexperimentais, ficção distópica-fantástica, e romances-reportagens, todas com a intenção de denunciar o regime.

A comunidade brasileira de ficção científica no país praticamente cessou suas atividades neste período, como efeito do autoritarismo. Antes disso, porém, alguns autores estiveram engajados contra a ditadura como, por exemplo, Jerônymo Monteiro e André Carneiro. Este último, inclusive, com participação na luta armada, escreveu algumas histórias curtas de FC sobre o período, como a novela "Sem Memória" (CARNEIRO, 2007) e o conto "Gabinete Blindado" (CARNEIRO, 2011), com claras referências autobiográficas.

Contudo, se a chamada Primeira Onda da FCB sofreu uma interrupção os escritos de FC continuaram pelas mãos de autores descompromissados com as tradições do gênero, mas que se exercitaram para criticar a ditadura militar. É pouco provável que

regime político menos autoritário, mas não necessariamente democrático, pois o objetivo principal era aproximar o país de um modelo político-econômico mais socialista. Nesse sentido, apenas os moderados militares e os moderados civis estavam, de fato, comprometidos com a transição de um regime autoritário para um democrático, ainda que os termos do processo tenham sido ditados, principalmente, pelos militares. (LINZ; STEPAN, 1999). Esta posição de força dos militares brasileiros só tem paralelo com o caso da transição chilena e explica porque tantos resquícios autoritários e dificuldades para investigar e julgar os abusos de direitos humanos cometidos permanece no país. 
estes autores próximos do mainstream literário identificassem suas obras como de ficção científica, mas o fato é que elas pertencem ao gênero, dentro do segmento temático das chamadas distopias. Desta forma foi por uma das três correntes acima citadas que tivemos obras de FC para criticar o regime militar. Em geral podemos definir as distopias como regimes políticos utópicos ao contrário, que perverteram os supostos ideais virtuosos em que teriam sido concebidos. Se a utopia trabalha com a noção de esperança de um mundo melhor que não existe, a distopia a converte em cenários reais de medo e pesadelo. (BRANCO, 2011a).

No caso brasileiro estes romances assumiram algumas características próprias, como a refletir, em termos principalmente metafóricos e alegóricos, os aspectos principais do regime militar. Os temas principais versaram na crítica à opressão, a crescente interferência burocrática do Estado, além de temas pós-materiais, como a ecologia e o feminismo - derivados de debates que eram travados nas sociedades afluentes do Primeiro Mundo, e que também tinham impactos numa sociedade capitalista em rápido processo de modernização dos papéis sociais e da exploração dos recursos naturais, como o Brasil.

Uma variante da ficção distópica pode ser encontrada na obra do fantasista José J. Veiga, como nas novelas A Hora dos Ruminantes (1966), A Máquina Extraviada (1968) e Sombra dos Reis Barbudos (1972). Eivados de momentos fantásticos que sublinham uma sensação de opressão e descontrole, servem como metáforas do contraste da vida simples (do mundo rural e do interior do país) e a chegada de um progresso de teor estranho e autoritário, que também ilustra a condição brasileira na época, de mudança em direção à modernização urbana e capitalista. ${ }^{10}$
Entre as obras de ficção distópica relevantes, mais próximas da FC no período podemos começar por citar Fazenda Modelo (1974), de Chico Buarque. Inspirada na novela $A$ Revolução dos Bichos (1945), de George Orwell, retrata um país imaginário que submete o gado a um processo rígido de acasalamento, controlando a sexualidade e a reprodução, numa alusão à regulamentação crescente da vida brasileira. Outra é O Fruto do Vosso Ventre (1976), de Herberto Sales, uma fábula tecnocrática com fundo religioso. A exemplo de $A$ Utopia (1516), de Thomas More, a história se passa numa ilha, autoritária e burocratizada ao extremo, em que todas as ordens do Estado e suas leis seguem esta lógica, mas com resultados contraditórios. É a obra mais importante a criticar a lógica tecnocrata levada ao extremo pelo governo militar nos anos 1970. Mais uma obra de interesse é Asilo nas Torres (1979), de Ruth Bueno, que trabalha a questão da repressão tendo como pano de fundo a condição subalterna da mulher numa sociedade opressiva.

Do ponto de vista da qualidade literária ou mesmo da contribuição para o desenvolvimento da FC brasileira o valor destas obras é passível de discussão. Afinal, por terem sido escritas por pessoas sem intimidade com o gênero acabam por se inspirar em clássicos literários - Admirável Mundo Novo (1932), 1984 (1949) -, além de apresentarem certa ingenuidade no tratamento de temas, trabalhados com mais desenvoltura no interior do gênero, mesmo as distopias, muito praticadas no contexto da FC nos Estados Unidos e na Grã-Bretanha, os centros mais desenvolvidos.

Em termos políticos, entretanto, podemos afirmar que esta corrente crítica da literatura brasileira dos anos 1970 conseguiu retratar de forma interessante as principais características da ditadura militar brasileira naqueles anos em especial: a alta repressão (prisões, exílios, torturas e assassinatos),

\footnotetext{
${ }^{10}$ Outro autor importante a trabalhar nesta vertente fantástica é Murilo Rubião. Para detalhes, ver Ginway e Causo (2010).
} 
crescimento econômico elevado mas socialmente concentrado e ambientalmente destrutivo, a censura e a crescente tecnocracia que controlava em demasia a vida do cidadão comum.

Este conjunto de temas nos encaminha para o que defendo como um novo momento no interior deste intervalo entre a Primeira e a Segunda Onda da ficção científica brasileira. Isso porque há um romance que estabelece uma espécie de transição entre a chamada ficção distópica e a que chamo de ficção da abertura. Refiro-me a Não Verás País Nenhum, de Ignácio de Loyola Brandão. Publicado em 1981, Não Verás País Nenhum recebeu críticas elogiosas no país e no exterior ${ }^{11}$ sendo visto por especialistas da FC brasileira como uma de suas grandes obras, mesmo tendo sido escrita por um autor do mainstream. ${ }^{12}$

Estamos no início do século XXI em São Paulo. A ditadura militar prosseguiu e perpetuou os métodos do governo autoritário, como a repressão e a burocratização nos mais diferentes segmentos da vida cotidiana. Temos como protagonista Souza, um ex-professor de História, aposentado de forma compulsória pelo regime, que trabalha como um burocrata entediado. Além da ditadura - ou como efeito dela -, o país está num processo crescente de degradação ambiental grave, com racionamento e reciclagem de água, calor intenso, alimentos artificiais, ausência de vida vegetal e animal, nascimento de crianças deformadas e mutantes. A floresta amazônica e as demais foram finalmente destruídas, inteiramente desmatadas e transformadas em desertos, o que explica as temperaturas altas durante o ano inteiro.

De fato, a maior parte das análises deste livro o toma como, principalmente, uma distopia ecológica. ${ }^{13}$ Embora não negue isso, o enfoque da análise deste trabalho procurará focalizar a estrutura política e suas consequências. ${ }^{14}$

Em acréscimo ao contexto ambiental caótico, o Brasil perdeu parte de seu território, principalmente o Nordeste, que se transformou numa reserva multinacional. Esta perda provocou um grande êxodo de nordestinos para o Sudeste, que os reprime ao construir grandes cercas em torno das áreas metropolitanas das grandes cidades. Assim é que se concentra nos arredores de São Paulo uma quantidade imensa de acampamentos, verdadeiro campo de refugiados dentro do próprio país. A perda do Nordeste refere-se aos efeitos de longo prazo da dívida externa - vista nos anos 1980 como impagável -, e o êxodo dos nordestinos remete ao dos anos 1970, quando eles - sem perspectiva econômica em sua região - migraram para o Sudeste para servir de força de trabalho não qualificada para ajudar a impulsionar a industrialização do país.

O trecho abaixo é ilustrativo:

[...] o Esquema ${ }^{15}$ não aguenta mais criar empregos artificiais. Está além da capacidade. Prefere o desemprego generalizado, problemas sociais, que uma dívida insuportável. Eles têm horror da dívida externa e ao mesmo tempo usam a dívida como justificativa para tudo. (BRANDÃO, 1985, p. 96). ${ }^{16}$

\footnotetext{
${ }^{11}$ Recebeu, por exemplo, o prêmio Illa, como o melhor livro latino-americano publicado na Itália em 1983, e foi resenhado no The New York Times Book Review.

${ }^{12}$ Na prática Brandão não é tão fora do ambiente da FC como quer parecer. Editou nos anos 1970 a revista Planeta, que publicava reportagens sobre temas afins à FC, como exploração espacial, parapsicologia e ufologia, além de contos de ficção científica e fantástico, de autores nacionais e estrangeiros.

${ }^{13}$ Ver, por exemplo, Krabbenhof (1997) e Ginway (2005).

${ }^{14}$ Numa palestra em São Paulo, em 2005, o autor afirmou que Não Verás País Nenhum é a conclusão de sua trilogia sobre a ditadura militar. Começou com sua instauração no romance Zero (1974), depois analisado o cotidiano na coletânea Cadeiras Proibidas (1977) e especulado o seu desfecho futuro em Não Verás País Nenhum.

${ }^{15}$ É o nome dado ao governo. É propositalmente vago, como a tentar explicar o regime autoritário mais como um sistema de poder compartilhado por elites militares e civis, do que por um foco de poder definido.

${ }^{16}$ O livro foi publicado em 1981, mas usamos a edição de 1985.
} 
Temos aqui, um primeiro exemplo de como o romance aborda os temas do período da abertura, se diferenciando das ficções distópicas precedentes, mais centradas na crítica do Brasil dos anos 1970.

Nesse contexto de repressão política e crise sócioeconômica, o melhor tipo de emprego possível é aderir ao regime, ou como militar ou burocrata. $\mathrm{Ou}$ as duas coisas, os tais 'militecnos', que atuam nas empresas estatais e cargos do Estado, uma alusão aos tecnocratas dos anos 1970, especialistas insulados como que à parte das instituições e dos costumes políticos. (MARTINS, 1985). Outro segmento do regime é o dos 'civiltares', responsáveis pela segurança e repressão. Tropas de cunho civilmilitar, mantidas pelo Estado e grupos privados que o apoiam. Aqui a referência é aos radicais, linhas-duras, tanto da comunidade de segurança militar, como dos grupos civis paramilitares que os apoiavam. Brandão sugere que estes setores voltaram ao poder e mantiveram o país no autoritarismo, "por não concordarem com as renovações efetuadas pelo Exército. Esta ala uniu-se aos civis radicais que não concordavam com as aberturas do Esquema." (BRANDÃO, 1981, p. 111).

A referência mais explícita no livro é quando comenta sobre "Os Abertos Oitenta". O tom adotado é irônico e debochado, como a colocar em dúvida se o processo de abertura seria bem-sucedido. Há várias passagens no livro sobre este período, em que critica o modo como o processo estava se desenrolando, como a revelar uma incompreensão, mas que revela sensibilidade sobre os rumos incertos à frente que o Brasil viveria. Souza e seu amigo Tadeu Pereira comentam:

\footnotetext{
- Quem diria que iria acabar assim? Tudo parecia tão promissor nos Abertos Oitenta.

- Murcharam rapidamente. Teve gente que nem percebeu.

- Estamos chegando à conclusão que nos deixamos enganar. No fundo, era previsível o que viria. Quantos homens da antiga ditadura não continuaram nos postos? (BRANDÃO, 1985, p. 97).
}

E mais adiante, Souza reflete sobre porque não deu certo:

\begin{abstract}
- Não é essa confusão que está aí. É outro tipo, vê se me acompanha. Ela estava instalada nos Abertos Oitenta e veio se ampliando. [...] Confusão ideológica, desencontros. Governo pensava uma coisa, oposição outra, mas oposição e governo pensavam igual, ao mesmo tempo. Direita tomava atitudes de esquerda e a esquerda de direita. Nenhuma posição era confortável, trazia segurança. Não havia, como ainda não há, nenhuma certeza, firmeza, decisão. Eu tinha um amigo, conservador como quê. Me trouxe um dia uma teoria que achei louca e reacionária, mas agora começo a cogitar. [...] Previa que os Abertos Oitenta instalariam um poder tão de direita, que terminaria à esquerda, socializado, ou o contrário." [...] Já desmoronaram todas as estruturas nas quais acreditávamos, confiávamos. Será que estamos numa fase de transição, de substituição? Ou o quê? (BRANDÃO 1981, p. 119).
\end{abstract}

No fundo, além da reflexão sobre o contexto político dos anos 1980, Brandão procura refletir, amplamente, sobre o fracasso do projeto de transformação capitalista do Brasil que teria falhado, por causa do modelo burocrático-autoritário e seu objetivo de transformar a todo custo o Brasil numa potência econômica e militar, nem que com isso sacrificasse a sociedade e seus valores.

Para Brandão, mesmo com o processo de abertura abrindo o caminho para o fim do regime militar, é como se especulasse que àquela altura o futuro do Brasil já estaria inviável. Seja política, social ou em termos ambientais. Nesse sentido, Não Verás País Nenhum é a distopia do país do futuro que nunca se realizou.

Outros romances situados em meados dos anos 1980 e que discutem - em chave de FC - o período, são $A$ Invasão, de José Antônio Severo (1979); A Ordem do Dia, de Márcio Souza (1983); Silicone XXI, de Alfredo Sirkis (1985), e Horizonte de Eventos, de Jorge Luiz Calife (1986). Mas ao contrário do romance de Brandão estes outros não têm a mesma discussão abrangente de questões. Nesse sentido, são menos ambiciosos, embora abordem aspectos importantes do período. O que contribui para isso é o fato de que não são distopias, 
não à maneira das anteriores dos anos 1970 e de Não Verás País Nenhum.

O que mais se aproxima deste padrão é $A$ Ordem do Dia. Publicado já no período da transição realiza uma crítica satírica que permeia vários aspectos do regime, em especial o comportamento dos militares, seus desmandos, abusos e contradições. Apresenta uma estrutura narrativa meio caótica, que serve para ressaltar estas características do regime. Silverman (1997) observa ainda que a obra é um comentário tragicômico sobre um regime político que se afirma como muito sério, mas na verdade beira um pandemônio, dados os seus problemas, a começar pela falta de legitimidade. Em todo caso, o enredo confuso e folhetinesco que inclui eventos relacionados à $\mathrm{FC}$ como, por exemplo, à aterragem de discos voadores em Brasília, é pouco efetivo em discutir de forma mais aguda as questões políticas da época ou de especular sobre possíveis alternativas para o futuro do Brasil.

Vale observar que Não Verás País Nenhum também apresenta esta verve satírica, mas a utiliza numa narrativa mais convencional para criticar com ironia e deboche as várias facetas da ditadura. É assim que Brandão nomeia vários fatos e períodos com nomes curiosos como, por exemplo, "A Era das Casuísticas" - uma referência às súbitas mudanças eleitorais para favorecer o governo -, e "A Era da Grande Locupletação" - alusão às elites civis e militares que, por meio da corrupção e do clientelismo, se beneficiaram.

Pois o aspecto mais farsesco de A Ordem do Dia encontra ressonância num livro publicado anos antes, A Invasão, mas que apresenta o cenário do Brasil de 1986 com uma peculiar redemocratização. Isso porque o país ainda continua sob o domínio dos militares. De forma curiosa, o autor elabora uma coalizão de poder em que estão presentes os militares e os cinco principais partidos políticos do país. Líderes democráticos de nossa história, como Ulysses Guimarães, Leonel Brizola e Pedro Simon confabulam com os militares sobre a necessidade de manter o equilíbrio de forças para assegurar a democracia no país. Como? Deixa transparecer certa falta de clareza conceitual sobre o que é uma democracia e uma ditadura, e talvez tenha ocorrido por causa do contexto incerto dos rumos da abertura quando ele escreveu o romance. Mas isso incomoda quanto à busca por uma especulação mais refinada sobre o momento político apresentado.

Neste contexto do que poderíamos, grosso modo, chamar de uma democracia tutelada pelos militares, a narrativa mostra os preparativos do Brasil em invadir Angola - a pedido do país africano -, para expulsar os cubanos. Ocorre que o governo angolano é comunista e pede aos militares brasileiros para expulsar os antigos aliados cubanos, pois estes estariam assumindo o controle do país. Mesmo com a promessa ao Brasil de exploração preferencial de diamante e petróleo, a premissa peca por falta de verossimilhança, já que os militares são, antes de mais nada, anti-comunistas.

A Invasão difere dos demais livros (dos anos 1970 e 1980) também por apresentar uma perspectiva menos negativa dos militares. A nota biográfica ao final do livro informa que o autor José Antonio Severo fez a cobertura para o jornal Gazeta Mercantil, de São Paulo, da sucessão do presidente Geisel, e tornou-se próximo de diplomatas e militares graúdos do regime.

Contudo, embora com premissas discutíveis, o romance termina por adotar um tom abertamente absurdo, com situações insólitas, erros de continuidade no enredo e soluções políticas sem sentido. Num dos exemplos, o presidente renuncia sem explicação alguma em plena campanha militar, e os militares e políticos que dirigem o país decidem, de súbito, restaurar a monarquia. Temerosos de um novo Brasil imperial em pleno século XX os demais países da América do Sul invadem o país ao mesmo tempo. O que fica de $A$ Invasão é que Severo não se posiciona claramente contra a ditadura, mas contra o sistema de poder como um todo. Nesse sentido, ecoaria algumas das posições de Brandão em seu 
romance, mas de forma menos elaborada, mais semelhante ao tom farsesco de Souza.

Já no caso de Silicone XXI, de Alfredo Sirkis, não há dúvida: ele posiciona-se a favor da democracia. Motivos para isso não lhe faltam, já que o autor testemunhou e militou nos movimentos de esquerda que combateram o autoritarismo durante a segunda fase, conhecida como os "anos de chumbo". Sirkis registrou este período no romance reportagem autobiográfico Os Carbonários: Memórias da Guerrilha Perdida (1981), premiado com o Jabuti e base para a minissérie de TV Anos Rebeldes (1992), da Rede Globo.

Sirkis imaginou uma solução inteligente para abordar o período da abertura e da transição, ao criar um romance "policial futurista", como anunciado na capa.

Em Silicone XXI estamos no Rio de Janeiro em 2019. A cidade mantém sua alcunha de "maravilhosa", remodelada em termos urbanos, com edifícios futuristas, ruas em formas de escadas rolantes horizontais e a presença cotidiana da informática e de robôs que executam de serviços domésticos a sexuais. O elemento policial da trama remete a uma série de crimes cometidos contra travestis - chamados de "andróginos" -, e traz ao caso o investigador José Balduíno - um protagonista negro, caso raro na ficção científica brasileira.

Os crimes são cometidos em um motel e a arma usada é uma pistola de raios laser - outro lugar comum da FC -, chamada de "Pistola L", de uso privativo das Forças Armadas. Este detalhe nos leva ao contexto de crítica aos militares. Isso porque quem está por trás dos crimes é o coronel Estrôncio, reformado do Exército que na condição de segurança do Museu Nuclear de Angra dos Reis, lidera um esquema de contrabando de lixo radioativo e um grupo paramilitar, os Filhos de Plúton, ambos também com a participação do diretor do museu, o Próton Nogueira.

O conteúdo crítico de Sirkis é endereçado aos setores militares entusiastas do desenvolvimento da energia nuclear no Brasil. Eles foram influentes na segunda metade da década de 1970 - sob a presidência Geisel -, quando foi construída a usina nuclear de Angra I, e o projeto de construção de mais duas, Angra II e Angra III. ${ }^{17}$ Embora a justificativa do governo tenha sido a de praxe, ou seja, o investimento de energia nuclear para "fins pacíficos" - devido à necessidade de mais energia para o desenvolvimento econômico do país - havia uma desconfiança justificada de que a principal intenção era possibilitar a construção de uma bomba atômica. ${ }^{18}$ Não Verás País Nenhum é outro destes livros que também discute, em termos mais breves, a questão nuclear. A certa altura do livro é citada uma grave explosão nuclear que teria ocorrido quando da instalação das usinas.

Do conjunto de livros deste período, Silicone $X X I$ é o único que apresenta o Brasil sob um regime democrático. Há um governo social-democrata apoiado por militantes ambientais - os verdes -, que assumiu o governo do Brasil em 2005 e desativou as usinas nucleares - vistas, então, como um entulho do autoritarismo removido. E é por isso que se forma este grupo paramilitar, de radicais inconformados, com o objetivo de restaurar a energia nuclear no país, mesmo que por meios ilegais e autoritários. Fundou até mesmo uma exótica corrente ideológica para justificar suas ações, o movimento atomista.

Embora nos dias de hoje tal comportamento possa parecer ridículo, o tema do processo de

\footnotetext{
${ }^{17}$ Angra I entrou em operação em 1982 e Angra II em 2000. Angra III deve entrar em operação nos próximos anos.

${ }^{18}$ De fato, isto foi provado em 1990, durante o governo de Fernando Collor de Mello (1990-1992), que mostrou o lugar em que, supostamente, seria usado como testes para explosão da bomba brasileira, a Serra do Cachimbo, entre o sul do Pará e o norte de Mato-Grosso. Ver Malheiros (1993).
} 
nuclearização do país foi candente nas décadas de 1970 e 1980, ainda mais porque conduzido sob a égide do autoritarismo o que, de certa forma, enviesou os eventuais méritos do uso de tal recurso energético. Sirkis está refletindo também sobre a postura radical de parte dos militares, os chamados linhas-duras, de memória pessoal muito viva por ter lutado contra eles nos anos 1970.

Ao batizar os militares rebeldes com o nome de elementos químicos e de componentes do átomo, Sirkis realizada um engraçado deboche com a postura arrogante e reacionária, tanto no discurso, quanto na prática, em voga no período em que o livro foi escrito. E vai além, pois o tal Estrôncio possui um pênis de silicone, que infla ao ser bombeado. Assim, os militares são também mostrados como sexualmente impotentes e ambíguos, já que o assassino faz sexo com travestis.

Mesmo ao situar a história no século XXI e em vigência de democracia, Sirkis alerta que os militares - mesmo que por vias tortas - continuariam como uma presença potencialmente desestabilizadora da política brasileira. Embora tal não ocorra nos dias de hoje, não quer dizer que não poderá voltar a ser num futuro indefinido.

O último livro que representa esta mudança de enfoque temático e perspectiva política dentro da FC brasileira é Horizonte de Eventos, de Jorge Luiz Calife (1986). Este é o segundo romance de uma celebrada trilogia de FC hard, ${ }^{19}$ iniciada com Padrões de Contato (1985) e finalizada com Linha Terminal (1991). ${ }^{20}$ Chama a atenção também que este é o único dos livros escritos por um autor vinculado às tradições temáticas do gênero. Isso quer dizer que Horizonte de Eventos transita com mais desenvoltura os temas e conceitos da FC, ao contrário dos outros livros.
$\mathrm{O}$ romance continua os temas abordados em Padrões de Contato. Os humanos vivem no espaço em enormes estruturas orbitais em formas de anéis, ao lado de extraterrestres. A história segue a trajetória de Angela Duncan, uma mulher tornada imortal por uma supercivilização que vive no centro da Via-Láctea, como parte de um plano de incorporação da humanidade numa espécie de comunidade galáctica, que poderia levar à perda de nossa individualidade como a conhecemos.

Em Horizonte de Eventos a história se situa em uma colônia anelar democrática e desarmada, chamada Éden 6, que de repente fica vulnerável a forças externas que não controla. Primeiro, é arrastada lentamente rumo a um horizonte de eventos, onde poderá ser tragada para o interior de um buraco negro. A seguir, uma descontinuidade no continuum do espaço-tempo traz de volta uma nave armada, vinda do século XX, chamada Brasil. Os tripulantes desta nave resistem à abordagem e ameaçam atacar. Para completar, uma raça alienígena de parasitas, os nictianos, quer assimilar Angela Duncan, para terem acesso aos seus poderes cósmicos e imortalidade.

Calife mostra a Brasil como sendo uma nave que veio do seu país homônimo, mas que devido a problemas durante a viagem, sofre um golpe e os militares assumem o poder. Eles instalam uma ditadura que se assemelha à do regime militar, com prisões, tortura e mortes de opositores.

Ginway analisa de forma arguta como Calife ilustra os eventos desta nave como um microcosmo do que ocorreu no regime militar brasileiro:

A falta de preocupações ambientais e humanas da parte dos militares é criticada no episódio em que, depois que a nave é atingida por um meteoro, os militares forçam os civis a viver em áreas radioativas,

\footnotetext{
${ }^{19}$ Ficção científica hard é aquela que aborda os temas mais tradicionais do gênero, ligados às ciências naturais (astronomia, física, biologia etc).

${ }^{20}$ Em 2009 os três livros foram reunidos em um só volume, Trilogia Padrões de Contato, pela Devir Livraria.
} 
enquanto o seu próprio pessoal mantém-se seguro. Uma rebelião civil contra essas condições é punida com os seus líderes sendo soltos no espaço, um ato de vingança que lembra o uso de desaparecimentos e exílios políticos pela ditadura. Finalmente, o fato de a Brasil ficar à deriva durante gerações em busca de um planeta para colonizar, simboliza o destino da nação durante os vinte anos de ditadura (GINWAY, 2005, p. 150-151).

Embora seja um dos raríssimos livros escritos por um autor identificado com a FC a criticar mesmo que de forma implícita - a ditadura, é tímido na reflexão dos seus possíveis efeitos para a sociedade brasileira, em processo de redefinição de seu futuro político.

\section{Conclusões}

O objetivo deste artigo foi mostrar que a despeito da periodização histórica da ficção científica brasileira assinalar que os anos 1970 e início dos 1980 foram de interregno no gênero, um período nomeado por Ginway e Causo (2010) de "onda utópica/distópica", os livros publicados nestes anos não se apresentaram somente como distopias, num reflexo das características do regime militar. Afirmamos que é possível dividir este período em pelo menos duas fases distintas e complementares, a primeira como a da ficção distópica - a criticar os "anos de chumbo", mais repressivos de 1968 a 1974 -, e uma segunda, mais voltada à fase da abertura política, entre os anos de 1974 a 1985, aqui chamada, na falta de um nome melhor, de "ficção da abertura".

$\mathrm{Na}$ primeira parte recapitulamos a trajetória do regime autoritário, com especial ênfase ao período da abertura, que terminou por conduzir o país à transição que encerrou o ciclo de duas décadas dos militares no poder. A perspectiva analítica seguiu a linha do chamado institucionalismo estratégico (O'DONNELL; SCHMITTER, 1988), que prioriza a interpretação dos processos de transição a partir das negociações políticas entre as elites civis e militares. Mesmo assim, foi mostrado o contexto social e econômico em que os atores políticos atuaram, ressaltando a importância dos grupos sociais e das características da economia dentro do ambiente político.

Mostramos que dentro desta periodização interna aos anos 1970 e parte dos 1980, o romance Não Verás País Nenhum, de Ignácio de Loyola Brandão cumpre uma espécie de elo entre as duas perspectivas temáticas (distopias e da abertura), sendo uma FC distópica mas que discute a fundo os temas dos anos 1980, numa fértil (e assustadora) especulação de um país que, embora em processo de mudança por mais liberdade, já estava com seu futuro condenado, por causa dos excessos políticos, econômicos e ambientais cometidos nos anos mais repressivos do autoritarismo.

As chamadas histórias de $\mathrm{FC}$ do período da abertura aqui discutidas - com a exceção do romance de Brandão -, não apresentam a mesma relevância temática para a $\mathrm{FC}$, e política para as perspectivas que se abriam ao Brasil no momento da transição. Ora pessimistas com as possibilidades da democratização, temerosas da presença militar como uma força desestabilizadora, e pouco reflexiva sobre as condições sociais possíveis num país de desigualdades tão evidentes. É certo que o que pode ter dificultado é que num regime político em processo de mudança, a acuidade de especulações torna-se mais difícil. Primeiro porque, num processo de transição, não se tem certeza se o regime político se tornará, de fato, democrático. A democracia é uma das possibilidades, não a única. (O’DONNELL; SCHMITTER, 1988). Segundo, porque os livros foram escritos num contexto de mudanças complexas, sem muita clareza sobre o que aconteceria, ou como. Alguém pode argumentar que a uma boa história de FC cabe justamente não se intimidar ou confundir com o momento presente, mas especular com alguma presciência sobre o que pode acontecer. Mas, afinal, quatro das cinco obras analisadas foram escritas por autores sem afinidade com a ficção científica. 
Por outro lado, constatamos o quão pouco a Segunda Onda da ficção científica brasileira se preocupou com o processo de mudança política ou o recente passado autoritário. Esta nova geração nasceu sob os ventos das mudanças democráticas, mas não tem tido entre seus temas de maior reflexão os efeitos do autoritarismo. Muito mais ligada às tradições temáticas da $\mathrm{FC}$, produziu nos anos 1980 e 1990 um conjunto de histórias dinâmicas e variadas, que procurou dialogar preferencialmente com os temas (e modas) da FC anglo-americana. Exemplos com resultados importantes são a história alternativa e o cyberpunk. ${ }^{21}$

Tais características não impediram, por vezes, uma bem vinda reflexão sobre a condição periférica do país no contexto internacional, bem como abordagens voltadas a assuntos mais caros à nossa realidade como, por exemplo, a desigualdade social e a soberania sobre recursos naturais. Assumiu, nestes momentos, uma brasilidade genuína, que a ajudou a buscar uma identidade própria e refletir um pouco mais sobre a sua cultura e História. Exemplares, entre outros, neste particular são a coletânea $O$ Fruto Maduro da Civilização, de Ivan Carlos Regina (1993) e Terra Verde, de Roberto de Sousa Causo (2000). ${ }^{22}$

Na verdade obras de ficção científica política que discutem o Brasil e seus problemas contemporâneos tem vindo mais do mainstream. Exemplos recentes incluem os romances Admirável Brasil Novo, de Ruy Tapioca (2001); Labirinto Digital, de Mário Kuperman (2004) e A Guerra da Amazônia, de Carlos Bornhofen (2004). Isto talvez demonstre que a política como tema de reflexão é de interesse geral, ao passo de ser um dos interesses possíveis aos autores vinculados à ficção científica brasileira.

Contudo, a reflexão sobre uma melhor abordagem específica para os anos 1970 e parte dos 1980 ainda é necessária - seja dos autores de FC ou do mainstream -, pois já se conta com a vantagem do tempo (e de novos estudos) para o que poderíamos chamar - no contexto da FC - de interpretações especulativas mais diferenciadas, sobre um período tão marcante e com efeitos ainda presentes na vida brasileira.

\section{Referências}

AVRITZER, L. O conflito entre a sociedade civil e a sociedade política no Brasil pós-autoritário: uma análise do impeachment de Fernando Collor de Mello. In: ROSENN, K. S.; DOWNES, R. (Org.). Corrupção e reforma política no Brasil: o impacto do impeachment de Collor. São Paulo: Ed. FGV, 2000.

BORNHOFEN, C. A guerra da Amazônia. Osasco: Novo Século, 2004.

BRANCO, M. S. Afinidades eletivas entre ficção científica e política. In: BRANCO, M. S. (Org.). Assembleia estelar: histórias de ficção científica política. São Paulo: Devir, 2011a.

Democracia na América Latina: os desafios da construção (1983-2002). São Paulo: Humanitas, 2007a.

- Não verás país nenhum. Resenha de: BRANCO, M. S.; SILVA, C. (Org.). Anuário brasileiro de literatura fantástica 2006. São Bernardo do Campo: Hiperespaço, $2007 \mathrm{~b}$.

\footnotetext{
${ }^{21}$ Nestes anos 2000, já na vigência da Terceira Onda - a partir de 2004 -, esta tendência prossegue, com o New Weird, a New Space Opera e o Steampunk.

${ }^{22}$ Causo tem sido uma exceção neste panorama, pois escreve histórias de FC do ponto de vista de personagens militares, como em "Patrulha para o Desconhecido" (CAUSO, 1991) - pracinhas brasileiros na Segunda Guerra Mundial -, "Capacetes Azuis, Verdes e Amarelos" (CAUSO, 1993) - brasileiros servindo nas forças de paz da ONU -, e Selva Brasil (CAUSO, 2011) - guerra na Amazônia. É uma postura polêmica, mas necessária, pois numa democracia consolidada é preciso que os militares tenham um tratamento menos vilanizado e mais integrado à realidade sócio-institucional do país. Mais detalhes sobre outras histórias de ficção científica política, ver Branco (2011a).
} 
. Silicone XXI. Resenha de: BRANCO, M. S.; SILVA, C. (Org.). Anuário brasileiro de literatura fantástica 2010. São Paulo: Devir, 2011 b.

BRANDÃO, I. L. Não verás país nenhum. São Paulo: Global, 1985.

CALIFE, J. L. Horizonte de eventos. Rio de Janeiro: Nova Fronteira, 1986.

CALIFE, J. L. Trilogia padrões de contato. São Paulo: Devir, 2009.

CARNEIRO, A. Sem memória. In: Confissões do inexplicável. São Paulo: Devir, 2007.

- Gabinete blindado. In: BRANCO, M.

S. (Org.). Assembleia estelar: histórias de ficção científica política. São Paulo: Devir, 2011.

CARVAlHO, J. M. Cidadania no Brasil: o longo caminho. Rio de Janeiro: Civilização Brasileira, 2011.

CAUSO, R. S. Patrulha para o desconhecido. Isaac Asimov Magazine, Rio de Janeiro, n. 13, 1991.

. Capacetes azuis, verdes e amarelos. In: DOREA, G. (Org.). Tríplice universo. São Paulo: Ed. GRD, 1993.

- Science fiction during the brazilian dictatorship. Extrapolation, Texas, v. 39, n. 4, 1998.

. Terra verde. São Paulo: Cone Sul, 2000.

. Selva Brasil. São Paulo: Draco, 2011.

GINWAY, M. E. Ficção científica brasileira: mitos culturais e nacionalidade no país do futuro. São Paulo: Devir, 2005.

- Visão alienígena: ensaios sobre ficção científica brasileira. São Paulo: Devir, 2010.

GINWAY, M. E.; CAUSO, R. S. Discovering and re-discovering brazilian science fiction: an overview. Extrapolation, Texas, v. 51, n. 1, 2010.

KUPERMAN, M. Labirinto digital. São Paulo: Marco Zero, 2004.

LAMOUNIER, B. (Org.). De Geisel a Collor: o balanço da transição. São Paulo: Sumaré, 1990.
LINZ, J.; STEPAN, A. A transição e consolidação da democracia: a experiência do sul da Europa e da América do Sul. São Paulo: Paz e Terra, 1999.

KRABBENHOFT, K. Ignácio de Loyola Brandão e a ficção do estranhamento cognitivo. In: CAUSO, R. S. (Org.). Ensaios internacionais de ficção cientifica brasileira. Brasópolis: Edgard Guimarães Editor, 1997.

MALHEIROS, T. Brasil a bomba oculta: o programa nuclear no Brasil. Rio de Janeiro: Gryphus, 1993.

MARTINS, L. Estado capitalista e burocracia no Brasil pós 64. São Paulo: Paz e Terra, 1985.

O’DONNELL, G. Análise do autoritarismo burocrático. São Paulo: Paz e Terra, 1990.

O’DONNELL, G.; SCHMITTER, P. Transições do regime autoritário: primeiras conclusões. São Paulo: Vértice, 1988.

REGINA, I. C. O fruto maduro da civilização. São Paulo: Edições GRD, 1993.

SEVERO, J. A. A invasão. Porto Alegre: Ed. L\&PM, 1979.

SILVERMAN, M. Resenha de A ordem do dia. In: CAUSO, R. S. (Org.). Ensaios internacionais de ficção cientifica brasileira. Brasópolis: Edgard Guimarães Editor, 1997.

SIRKIS, A. Silicone XXI. Rio de Janeiro: Record, 1985.

SKIDMORE, T. A lenta via brasileira para a democratização: 1974-1985. In: STEPAN, A. (Org.). Democratizando o Brasil. São Paulo: Paz e Terra, 1988.

SOUZA, M. A ordem do dia. Rio de Janeiro: Marco Zero, 1983.

STEPAN, A. Os militares: da abertura à nova república. Rio de Janeiro: Paz e Terra, 1986.

TAPIOCA, R. Admirável Brasil novo. Rio de Janeiro: Rocco, 2001.

VEJA. São Paulo: Abril, n. 854, 16 jan. 1985. (ed. especial).

Recebido: 21 maio 2013. Aceito em: 25 out. 2013. 
